\title{
El teatro en la obra de Ricardo Rojas
}

NTRE los múltiples aspectos que la polifacética personalidad de Ricar-
do Rojas presenta a la exégesis no es el menos significativo el referente a su contribución al teatro argentino que en el conjunto de la opera omnia abarca triple campo: critica, investigación y creación. Y he de referirme a él por cuanto fue uno de los motivos - no el primero, por cierto-que me aproximaron al maestro, pródigo en incitaciones y diálogo.

Me acerqué a Rojas, allá por 1936 , cuando debí cursar como alumno de la Facultad de Filosofía y Letras de Buenos Aires el ciclo de Literatura Española en la Sección Letras. Rojas dictaba la materia y había elegido como tema de programa para dicho año, la épica castellana. Y ese curso que en el papel amenazaba de pesadez, con piezas de museo como La Cristźada, de Hojeda; El Monserrate, de Virués o La Austriada de Ruffo, cobró a través de la palabra cálida del expositor, a través de las sabias conexiones que trazara, un atractivo singular, una iluminación de posibilidades inusitadas.

De una de ellas - ensayada inicialmente a manera de trabajo práctico de la cátedra- nació mi primer libro: La poesía épica y el alma infantil que con no poco rubor cito, sólo por recordar que llegó a las letras de molde por estímulo de Rojas quien, además, le dio el espaldarazo de las líneas que escribiera para insertar como prólogo del mismo.

Con tal motivo, pues, comencé a tratar más de cerca a Ricardo Rojas; le conocí en su casa señorial, en su ámbito de trabajo; le intuí maestro y arquetipo y a él volví cada vez que anhelé un reencuentro con nuestras esencias. De allí que naturalmente acudiera a Rojas el día en que dispuesto a abordar la tesis doctoral, el teatro argentino reclamara mi interés.

Rojas me proporcionó entonces no sólo el tema específico sino, además, guía, orientación y, sobre todo, su diálogo fundamental con nuestra 
dramática sostenido a través de la triple relación de crítico, investigador y creador, que en él se conjugaban.

De crítico que, actuante en los comienzos de siglo, en el alborear de una dramática nacional, se mostró atento al ritmo universal del teatro para la selección sagaz y trascendente, capaz de enriquecer con enseñanzas provechosas a los esforzados sostenedores de nuestra escena en la hora inicial. De investigador que supo sacar a luz y evidenciar las raíces soterradas de un teatro aparentemente nuevo al tiempo de estimular generosamente a otros para proseguir ese rastreo por él iniciado. De creador que no sólo aportó obras fundamentales a la literatura dramática, sino que las eslabonó y proyectó en una doctrina estética general expresada en las páginas de Eurindia.

De estos tres aspectos que conciernen al teatro en la obra de Ricardo Rojas quiero dejar aquí algunos testimonios.

De Rojas crítico teatral quedan en las páginas de El País las vislumbres augurales de nuevos valores rioplatenses asomados a la escena argentina durante la primera década de este siglo, cuando la aventura de ex-saltimbanquis convertidos en actores hizo realidad los sueños ancestrales de un teatro vernáculo. Rojas recordaba particularmente una de entre ellas: la profecía entusiasta que abrió camino a Florencio Sánchez, formulada tras asistir a la lectura de $M^{\prime}$ 'bijo el dotor en la redacción de El Pás y reafir. mada, luego, en las urgencias de la noche de estreno.

Cuando en abril de rgrr, en el Teatro Odeón de Buenos Aires, se congregó el primer homenaje póstumo al autor de La gringa, así lo subrayó la palabra vibrante del maestro, reclamando aquellas primicias:

Yo fui-dijo entonces- de los primeros en aplaudir a Sánchez, cuando llegara, incógnito, a esta enorme ciudad donde sus obras le popularizaron después...

Yo, que por aquellos años había llegado también de la provincia interior, comprendía el éxodo del nuevo camarada que venía de una tierra amada y vecina y desde aquel instante nos unimos, por sueños de arte y de emoción indiana, en amistad sin reticencias que los éxitos no disminuyeran...

Yo asistí a la lectura privada de M'bijo el dotor en El País y de $L a$ gringa en casa de un amigo común. Público fue mi aplauso, sin esperar la muerte, $y$ he releído en estos días - confieso que con alguna íntima satisfacción por el acierto del anuncio y del juicio que los años siguientes rati. ficaron-la página presurosa y entusiasta que dediqué a M'bijo el dotor la noche del estreno... 1

1 Discursos. (Buenos Aires: La Facultad, 1924), XI, pág. 189. 
De Rojas crítico teatral queda, además, la bizarría juvenil con que en más de una ocasión rompió lanzas contra prejuicios resabiados que negaban acceso a las carteleras a ciertas obras y autores; bizarría inflamada de militancias en el lirismo socialista cultivado por la intelectualidad de principios de siglo. Y para esos autores y obras por los cuales se batió tuvo, sin embargo, la medida justa, el rasero que descartó la paja del grano, sin dejarse deslumbrar por fáciles dialécticas o las circunstancias de tal o cual fama precedente.

Baste aquí recordar para el caso los episodios relacionados con el estreno porteño del drama de Benito Pérez Galdós: Electra; episodios que hablan de un tiempo batallador en el historial del teatro rioplatense, mucho más activo y vital, por cierto, que el que nos toca sobrevivir.

Como se sabe, el drama de Galdós enfrenta, a través del espíritu abierto de Máximo, el joven sabio, y de Pantoja, el tétrico santurrón, las fuerzas progresistas y las fuerzas conservadoras, respectivamente, que juegan en los ritmos sociales de la humanidad.

Cuando Galdós estrenó el drama, en enero de I901, se promovieron a su alrededor, en España, agrias cuestiones. A los pocos meses del sonado estreno madrileño, nada menos que tres compañías - la de Mariano Galé, en el Teatro Argentino; la de Andrés Cordero, en el Teatro de la Victoria; la de Manuel de la Vega y Joaquín Montero, en el Comedia-anuncian simultáneamente su representación para el público de Buenos Aires. Se mueven algunas influencias oscuras para impedirlo $y$, en prevención de posibles incidentes, se toman precauciones policiales. Pero, si damos fe a las crónicas de la época, la policía resultó impotente para contener a los grupos entusiastas.

Según Mariano G. Bosch, en el incidente tuvo primordial actuación el líder socialista, Dr. Alfredo L. Palacios, quien, dice Bosch, "en plena era de propagandas entusiastas y gritonas - que habían de llevarle a una diputación- desde un palco tomó la palabra y pronunció un discurso altisonante contra el clericalismo. La policía le impidió continuar, pero el público en masa protestó y vociferó de tal manera por este atentado contra 'las libertades ciudadanas' y la libre emisión del insulto popular que ésta fue la mejor manera de cortar el discurso. Entonces salieron tumultuosamente a la calle en manifestación". ${ }^{2}$

Rojas, en El País, se hace eco de la resonancia que adquiere la obra

2 Historia de los origenes del teatro nacional argentino y la época de Pablo Podestá (Buenos Aires, J. L. Rosso, 1929), pág. 76. 
galdosiana y, al tiempo que la juzga imparcialmente, trata de buscar explicación al fenómeno social que ha reportado. La halla en razón de oportunidad:

Todo tiene su hora-explicam-; y si algunos autores fracasan es, no siempre por falta de mérito, sino a causa de anticipaciones impremeditadas o retardos imprudentes. Para elegit ese instante oportuno también se necesita talento. La hora para Electra había llegado; y Galdós lo ha tenido si acaso la aparición de la obra no ha obedecido a circunstancias accidentales. ${ }^{3}$

\section{¿Por qué, según Rojas, Electra llega oportunamente? Porque}

...los acontecimientos que, en lo social y en lo político, vienen agitando desde hace tiempo a la península ibérica; los nuevos rumbos que los últimos desastres internacionales han determinado en el espíritu público español (he ahí por qué ha sido benéfica a España la guerra con Norte América); el célebre proceso de la señorita Ubao; y, por fin, el casamiento de la princesa de Asturias, que ha despertado tan grandes resistencias en la península amenazada de reacción absolutista; todo eso, unido a las pequenas causas que, como en todos los momentos históricos, actúan quizá inadvertidas, pero siempre eficazmente, en las evoluciones sociales, venian cargando el ambiente del oxígeno que debía dar vida a una obra como Electra. ${ }^{4}$

Rojas estima que, en momentos tales, la literatura siempre aporta poderosas fuerzas de acción:

El escritor - afirma- que casi siempre aparece en la hora de estas grandes crisis históricas, cuando ha sabido penetrar hasta lo más intimo del ambiente en que vive, condensa en su obra el peligro y el remedio vagamente presentidos por la conciencia colectiva. De ahí que se pueda considerar el triunfo de Electra, ante todo, como un éxito político y que la obra, buena o mala, desde el punto de vista literario, ha servido para revelar que las aparentes conquistas del clericalismo no son sino las agitaciones agónicas de los cuerpos que mueren...5

Tras un prolijo examen técnico-literario de la pieza, cuando llega el momento de condensar el juicio estético, al margen del "compromiso", Rojas no trepidará en afirmar:

De ahí que Electra adolezca de gravísimos defectos, algunos muy fundamentales, y de exageraciones que llegan quizá a deformar la obra y a borrar

3 "Electra: el ambiente, la obra y su doctrina", El País, 28 de marzo de 1901.

4 Ib. id.

5 Ib. id. 
en parte sus verdaderos lineamientos; pero que se explican cuando uno se remonta a su génesis psicológica.

A pesar de todo lo manifestado creo que el verdadero autor de la Electra que ha alcanzado un éxito tan formidable, no es Galdós, sino el público. ${ }^{6}$

Así, justas, sin ataduras, fueron las críticas de Rojas. Tal fue Rojas crítico teatral; no el cronista elemental que anoticia o describe, sino el orientador, el que analiza, el que escruta, el que hace de la tribuna periodística, cátedra y magisterio, a la vez ágil e informativa.

Con Rojas investigador el teatro argentino tiene larga deuda que saldar. Cuentan en ella: primero, su aporte personal; luego, la obra realizada desde el Instituto de Literatura Argentina de la Facultad de Filosofía y Letras de Buenos Aires; por último, el haber sabido despertar vocaciones de nuevos investigadores que han rastreado las lejanas vertientes y han afirmado la fisonomía vernácula de la dramática argentina.

Por de pronto hay, en Rojas investigador, la discriminación esencial de los orígenes de nuestro teatro. Frente a afirmaciones gratuitas o interesadas que borraban de un plumazo todo el pasado teatral argentino anterior a Juan Moreira, prueba la falacia de tales asertos, exhumando, tras pacientes búsquedas, un denso repertorio de inconfundible aire local, que se remonta a los días de la Colonia y revela la continuidad de esfuerzos tendientes a plasmar esa dramática nacional.

En las páginas pertinentes de La literatura argentina - su obra fundamental de investigación literaria - puede percibirse la justa valoración del verdadero significado de Juan Moreira y de los Podestá, sus intérpretes, en los orígenes del teatro nacional argentino; y, sobre todo, el desbaratamiento de aquella tesis de Vicente Rossi, condensada en las palabras finales del libro Teatro nacional rioplatense, según la cual en Argentina no hubo teatro antes de I884 $\mathrm{y}$, después de esa fecha, lo hubo gracias a algunos cómicos uruguayos, por lo que "... el teatro nacional argentino pudo llamarse deliberadamente uruguayo; si no se llamó así fue por descuido de los orientales..."

Rojas explica el exacto sentido del Juan Moreira y lo ubica precisamente en una de las varias líneas evolutivas de nuestra actividad escénica -no la única y excluyente, desde luego-; y demuestra asimismo cómo, dentro de esa línea, Juan Moreira es etapa de un proceso incubado en la entraña misma de la poesía de los gauchescos, en el cual, "completada la formación lírica del canto nativo, en el ciclo de los payadores anónimos

6 Ib. id. 
- la payada tiene esencia dramática - la hemos visto metamorfosearse con Hidalgo (cuyos Diálogos patrióticos son teatrales), y empezar esa formación épica que termina con Hernández, para metamorfosearse nuevamente, con Gutiérrez, dando lugar a la formación dramática de nuestro teatro nacional, que nació como sainete o pantomima de gauchos". ${ }^{7}$

Pero la sola circunstancia del éxito de la pantomima circense, como factor biológico, no hubiese bastado para plasmar un teatro propio si no hubieran concurrido otras circunstancias vitalizadoras, que Rojas tipifica así:

Cuando después de 1880, el Juan Moreira, de Eduardo Gutiérrez, se transformó de pantomima en drama, trayendo a sus ingenuos intérpretes del circo al tinglado, y cuando los Podestá, que eran dichos intérpretes, "prosperaron hasta representar La piedra de escándalo, de Martín Coronado, se produjo un suceso de tales consecuencias que debemos considerarlo como punto de arranque de un nuevo proceso formativo, genuinamente criollo, por la índole de las obras y de los actores; pero no de un nacimiento, porque aquello sólo fue la conjunción de dos corrientes sociales: la campesina o folklórica y la urbana o literaria, que ya otras veces habían coincidido en los teatros porteños desde la época colonial. ${ }^{8}$

Y, a continuación, el maestro acude también para explicar este hecho del teatro argentino, a la doctrina culturológica fundamental que sostiene toda su obra de investigador y exégeta de lo argentino: indianismo y europeísmo, luego condensada en Eurindia:

Mi fórmula de indianismo y exotismo-dice-que suelo aplicar a la interpretación de todos nuestros fenómenos políticos, es de iluminadora pertinencia cuando se trata de nuestra historia intelectual, y particularmente en el caso de Gutiérrez y de nuestro teatro. El genio indígena separadamente nos habría dado la payada, el pericón y la pantomima circense, formas dramáticas embrionarias; el magisterio exótico separadamente nos habría dado el actor, la escena y la técnica teatral, pero sin contenido nativo: aquello no llegaba a la plenitud de la belleza; esto no llegaba a la intimidad de la nación. En la cópula fecunda de los dos elementos se hallará nuestra aptitud creadora: ni el criollismo indocto ni el transplante mecánico puede ser el ideal de nuestro atte. El Juan Moreira fue célula germinal de aquella cópula, pero no la única, y menos aún la primera. Pareció la primera porque el cosmopolitismo reinante había hecho olvidar a las clases cultas la historia literaria del país; y el ensayo prosperó porque el pueblo reconoció instintivamente su propia obra. 9

7 Los gauchescos, II. (Buenos Aires: La Facultad, 1924), Cap. XXVIII; pág. 901.

8 Los modernos, II. Id. Cap. XVII, pág. 824.

$9 \mathrm{Ib}$. id, pág. 825 . 
Numerosos autores y obras teatrales del siglo pasado, prácticamente desconocidos por las generaciones primeras de esta centuria, fueron exhumados y sacados del olvido por Rojas a lo largo de cursos universitarios, conferencias, opúsculos y desde las páginas de La literatura argentina. Pero su labor como investigador en lo concerniente al pasado teatral argentino fue más lejos aún al organizar en el Instituto de Literatura Argentina las dos secciones que le atañen. La primera -Origenes del Teatro $\mathrm{Na}$ cional-dedicada a la publicación de textos dramáticos primitivos, dio a conocer más de cuarenta títulos, muchos de los cuales jamás habían sido editados. Quizá hoy, con la mayor divulgación y adelanto de las técnicas filológicas, algunas de esas ediciones puedan parecer limitadas, pero lo cierto es que aun así han llenado cumplidamente sus funciones, revelando un repertorio y documentando la continuidad de la producción dramática local desde los albores del siglo XIx hasta Juan Moreira. La segunda sección-Noticias para la bistoria del teatro nacional- reunió importantes estudios sobre autores, actores y obras que constituyen útiles fuentes de consulta. La deuda del teatro argentino para con Rojas investigador se hace aquí particularmente elevada porque como maestro interesó e inició en la indagación del pasado teatral argentino a sus oyentes, a sus discípulos, a sus lectores, despertando y orientando vocaciones de técnicos y escoliastas que han ido creando el corpus histórico del teatro vernáculo. Precisamente, los títulos que forman la serie de Noticias para la bistoria del teatro nacional, constituyen trabajos de seminario o prácticas de cátedra, dirigidos por Rojas; y sus autores, los que en cada ocasión fueron oyentes y discípulos.

De Rojas creador dramático, autor teatral, el repertorio nacional ha recogido cuatro piezas que, ordenadas según respectivas fechas de estreno, son: Elelin, en 1929; La casa colonial, en 1932; Ollantay, en I939; y La salamanca, en 1943 .

Rojas no ha compuesto sus piezas teatrales al azar de la inspiración momentánea, fugaz, sino que cada una de ellas forma parte de un elaborado criterio que las sitúa en preciso eslabonamiento dentro de la propia producción del maestro, por una parte; y en certera conexión con los más ilustres antecedentes conocidos del pasado teatral hispanoamericano, por otra. Así, por ejemplo, al escribir Elelín, problema de conquistadores españoles en el medio indiano hostil, tiene presente la predecesión del Siripo de Lavardén, del Molina de Manuel Belgrano, de la Lucia Miranda, de Ortega. Cuando compone La casa colonial, comedia de aire moratiniano con desencuentros familiares por reflejo político, están presentes El bipó- 
crita politico, anónimo documento porteño que llevó al teatro el ambiente doméstico de la primera década de la patria; y el 1810, de Martín Coronado. Cuando concibe Ollantay, tragedia indígena, se engarza en la tradición del Molina, de Belgrano; del Tupac-Amarú atribuido a Luis A. Morante. Cuando elabora La salamanca, misterio colonial, desfilan en sus recuerdos las 'comedias a maravilla', las 'comedias de santos', los 'autos', que el teatro español transplantó al Nuevo Mundo.

Pero, además, en conjunto, la concepción dramática de Rojas está sustentada en dos columnas que empinan sendas teorias estéticas: una, específicamente referida al teatro; otra, general y culturológica, que Rojas, por otra parte, refiere tanto a la propia producción cuanto al ajeno quehacer intelectual hispanoamericano, al interpretarlos, según ya se adelantó, como una cópula entre el viejo acervo cultural de Occidente y el ancestro de Indias. ${ }^{10}$

La primera de ellas, doctrina dramática, comienza a ser formulada públicamente por Rojas desde el prólogo que encabeza la edición de Elelin, en $1929 .{ }^{11} \mathrm{Y}$ es una doctrina que conserva aún toda su validez, porque supone una interpretación esencial del hecho estético que el escenario comporta; y, por lo demás, plenamente coincidente con la que en nuestros días defienden ilustres teorizadores del teatro occidental. En ella, Rojas entiende que la escena no debe ser reproducción fotográfica de la vida, sino su transfiguración estética. No significa esto que se pronuncie por un antirrealismo, sino que sólo toma la realidad como punto de partida para el trascender. Así como Ortega y Gasset decía que en el arte la realidad sólo ha de ser cual el suelo para el bailarín, leve apoyo para

10. Vid: Eurindia (Buenos Aires, Ed. Losada, S. A.), 1951.

11 Entiéndase bien que la fecha y la ocasión precisan sólo la formulación pública de los conceptos, los cuales han sido elaborados mucho antes en el esquema estético de Rojas y llevan la impronta del modernismo y del arte puro. Sobre el particular hay interesante testimonio del propio Rojas en el capítulo LXXXVI de Retablo español (Buenos Aires, Ed. Losada, S.A., 1938), al recordar su encuentro en Madrid con Ramón del Valle-Inclán; testimonio recogido también por Ramón Gómez de la Serna en la biografía del autor de las Sonatas.

Refiere Rojas que salían con Valle-Inclán del estreno de Señora Ama y comentaban el inmediato realismo de la pieza, su fuerte sentido paisajista, la transcripción casi fonográfica del habla cotidiana, el dramatismo simple y violento en los caracteres. A todo ello, Valle-Inclán opinó: "A mí no me gusta un teatro de esa manera. Con los recursos de presencia que el teatro tiene, nos echa a la cara trozos de realidad. El arte no existe sino cuando ha superado sus modelos vivos mediante una elaboración ideal. Las cosas no son como las vemos sino como las recordamos. La palabra en la creación literaria necesita, siempre, ser transladada a ese plano en que el mundo y la vida se idealizan. No hay poesía sin esa elaboración".

Esto ocurre en 1908. Obsérvese la coincidencia esteticista en la actitud posterior de Rojas creador dramático. 
proyectar su etereidad, Rojas en la creación dramática busca trascender la inmediatez de la realidad próxima hacia el plano de la universalidad, del símbolo.

Así expresa en el prólogo de Elelín:

El teatro no es sólo recreación: es también creación; por eso no agota sus posibilidades en la simple copia del modelo exterior, que es de suyo limitado y estático, sino que busca inspiración inmediata en las fuentes dinámicas de la vida, interpretando directamente los caracteres, las pasiones, los ideales, hasta darnos en símbolos concretos y animados, una revelación del destino. ${ }^{12}$

Por verlo demasiado aferrado a un realismo externo, Rojas teme por el futuro del teatro criollo: prosa, atributos gauchescos o arrabaleros, remedo mecánico de hablas y jergas, de tipos cosmopolitas y ambiente burgués no han bastado para dar visión esencial de la vida argentina. Por eso advierte:

Nuestro teatro nacional, tan fértil en su democrático tealismo, corre peligro de esterilizarse si se reduce a la circundante realidad, porque la verdadera vida del individuo y de la patria, dilátase en la especie, más allá de sus apariencias actuales. 13

Tras esas apariencias, tras esa actualidad, subyace lo permanente y esencial de lo argentino, es decir, de la vida, del hombre. Y el creador estético ha de trascender aquéllas, en busca de éstos.

Para ese trascender, por lo que atañe al teatro, Rojas propone lo que denomina "evocación histórica", apoyada en la intuición poética.

Trascender dichas apariencias-escribe-, en el tiempo mediante la evocación histórica, en el espacio mediante la extensión geográfica, en el espíritu mediante la intuición poética, es enriquecer el repertorio de los temas, el acervo de las imágenes y el contenido psicológico que así alcanza una mayor universalidad.14

Pero, por "evocación histórica" no ha de entenderse el puro teatro histórico, la teatralización escolar de la noticia o el dato pretéritos, "sino a la creación artística que, al interpretar y representar la vida humana, puede igualmente hacerlo con temas del presente o del pasado". ${ }^{15}$

12 Elelin (Buenos Aires, La Facultad, 1929), pág. 8.

13 Ib. id.

14 Ib. id.

$15 \cdot I b . i d$. 
De ese trascender, de esa evocación histórica, surgirá un teatro poético; poético, aunque transcurra literariamente en prosa, porque alejarse del realismo fotográfico es, para Rojas, alejarse de lo prosaico cotidiano y penetrar en los dominios de la poesía. Coincide con ello, una vez más, con Ortega, cuando éste declaraba que ser apegadamente fiel a la realidad en materia artística es negar el arte. "Porque (en este caso) con la palabra realismo se quiere significar de ordinario una carencia de invención y de amor a la forma, de poesía y de reverberaciones sentimentales. Realismo es, entonces, negación del arte". ${ }^{16}$

Rojas prolonga a lo largo de toda su labor dramática la vigencia de esta doctrina estética enunciada desde la obra inicial. $Y$ así, en la carta que en octubre de 1937 dirige a Roberto F. Giusti, enviándole el libreto de La casa colonial para su publicación en la revista Nosotros, reitera:

Bien sé lo que ocurre con nuestro teatro nacional, desvirtuado por la peligrosa vecindad del cinematógrafo, por el realismo caricaturesco, y por un empeño mercantil que satisface a cierto público anheloso de reirse y de no pensar. 'Demasiado drama hay en la vida real para ir a entristecerse con los dramas del teatro', dicen muchos espectadores de hoy; pero ciertamente el teatro realista no es sino una continuación de la realidad. La risa solamente física no pertenece a la pura emoción estética. La mejor evasión de la triste realidad que nos rodea es la del teatro poético, del que la historia es su mejor fuente. No me refiero al teatro didáctico, que hace también realismo a su modo con los temas históricos, sino a que el pasado, con sus modelos lejanos, ofrece asuntos y apariencias de más fácil estilización. De ahí que esa especie dramática nos presenta la vida humana en su belleza, y su dolor inevitable se transfigura en la dulce emoción que los griegos hallaban aún en sus más terribles tragedias.

A través de estos conceptos, Rojas nos acerca a la segunda de las doctrinas que constituyen el fundamento de su creación dramática; doctrina culturológica general que supone, intrínsecamente, una interpretación de lo criollo que se integra dentro de la fórmula de Eurindia, credo de simpatía americana y libertad personal, complejo de cultura europea y atracción telúrica de Indias, exotismo e indianismo, según la sintesis expresada por Rojas.

En su aplicación al teatro la doctrina de Eurindia toma de la cultura y tradición occidentales, los principios formales del género en que se expresa. Técnica, procedimientos, estructuras dramáticas utilizados por

16 Ortega y Gasset: Obras Completas. Tomo I. "Del realismo en pintura". (Madrid, Revista de Occidente, 1950), pág. 568. 
Rojas en el quehacer teatral están enraizados en la ascendencia grecolatina, en la Edad de Oro hispana y, en algún aspecto, en el mejor romanticismo europeo.

En cambio, los temas, los símbolos, la presencia del medio, la magia y el misterio de lo telúrico, cierto fatalismo y el aire poético son de raigambre indianista.

Rojas cree que toda una civilización prosperará algún día como producto de esa síntesis y el teatro será como su avanzada y, a la vez, revelación a las nuevas comunidades de aquellos avatares y arcanos que elevan los orígenes al plano del mito. Así, al presentar Ollantay, la tragedia de los Andes podrá afirmar: "Hay en la tierra y en el tiempo misterios que el teatro debe revelar, como se los reveló religiosamente al pueblo griego. La leyenda de Ollantay nació en edades primitivas, y mi poema aspira a mostrar el misterio de los Andes y su liberación, idealizando el mito telúrico del continente en una obra de arte surgida de las más viejas tradiciones americanas". ${ }^{17}$

Resultado de ella, Ollantay, por su contenido legendario, por su hálito fatalista, es una tragedia, "pero no a la manera seudoclásica en cuanto a las formas de la composición, sino de otra manera: la que busca en la mentalidad primitiva, así en Grecia como en América, la inspiración de los mitos, representados en la escena por hombres vivientes". ${ }^{18}$

La producción dramática de Rojas ha seguido una marcha cíclica acorde con los ritmos culturales que de este continente hasta ahora conocemos. En Ollantay, el mundo precolombino con sus mitos religiosos, se contiene en los moldes trágicos, dinamizado por la voluntad heroica del protagonista en un clima de poesía y fatalidad. Con Elelín, el ciclo de la conquista se carga de las sordas pasiones y ambiciones que movieron a aquellos aventureros; los instintos se mezclan con los sueños, y el reino quimérico de Elelín se enturbia de asechanzas, de adversidades, de toda aquella sordidez que quiso tapar con la cruz, el crimen y la depredación. Con $L a$ salamanca, misterio a la manera del teatro religioso europeo, el mundo de la dominación española muestra cómo interfieren en curiosa y reveladora mezcla, supersticiones indígenas y cristianas, en el clima feudal de las encomiendas. Y el Zupay de las viejas supercherías, el Runauturunco, la Mulánima, el Basilisco, monstruos míticos de aquelarres infernales, enfrentan en la cueva embrujada - la Salamanca de las leyendas españolas, la Salamanca de los espantos indígenas-al Peregrino, misterioso

17 Ollantay (Buenos Aires, Ed. Losada, S. A., 1939), pág. 11.

18 Id., pág. 12 . 
personaje bajo cuya forma Cristo vuelve a la tierra para salvar a la Doncella, víctima de secuestro mágico. La salamanca, cronológicamente la última pieza teatral que estrenara Rojas, revela ya la conjunción teocosmogónica que espiritualmente entraña la fórmula de Eurindia. Y con La casa colonial, el mundo de la emancipación criolla enfrentado al hispano, a través de la conjuración de Alzaga, al proyectar el derrumbe del rancio hogar español de Don Anselmo Aranda, deja en el símbolo del rancho humilde de paja y barro - nido de horneros-en que empiezan a vivir su felicidad los hijos americanos, la afirmación y triunfo de lo criollo, arranque de una nueva etapa de civilización que ya no será Europa ni Indias, sino Eurindiut, síntesis de ambas, pero distinta de cada una de ellas.

No podrá juzgarse el valor de la dramática de Rojas por la resonancia popular que obtuviera. Elelín y La salamanca fueron tibiamente acogidas con ecos de procedencia intelectual. La casa colonial tuvo el aplauso generoso del público, pero la situación política del país bajo estado de sitio y los valientes planteos personales de Rojas que le llevarían al destierro fueguino, hicieron que la pieza bajara de cartel. Sólo Ollantay, presentada espectacularmente en el Teatro Nacional de Comedia por el director Antonio Cunill Cabanellas, recogió sostenida adhesión del espectador. Sin embargo, en Rojas había un hombre de teatro que manejaba con progresiva soltura los resortes dramáticos, razón por la cual sus piezas - todas de excelencia literaria y cuidada arquitectura - han de contar básicamente en el repertorio vernáculo.

Rojas, como creador dramático, llevó al teatro la responsabilidad de un prestigio, jerarquía intelectual, dignidad artística, reflexiones provechosas sobre el quehacer escénico y su sentido argentino, el desbrozamiento de una temática ardua que reclama cultores de su talla.

He aquí, en resumen, el aporte de Rojas al teatro nacional: como crítico, la orientación y el estímulo. Como investigador, el instinto certero de las conexiones y la recuperación de un pasado premonitorio para nuestra dramática. Como creador, una serie de obras estrenadas con dispar éxito de público y verdadera estima de la crítica, que sustentan un criterio dramático orgánico fundado, estéticamente, en la superación del realismo fotográfico por la trascendencia poética $y$, culturalmente, en la doctrina de Eurindia.

Tal, pues, la ubicación y el significado del teatro en la obra de Ricardo Rojas.

Raúl H. Castagnino, Universidad Nacional de La Plata, Argentina. 